\title{
Antimicrobial Finishing of Organic Cotton Textiles with Extract of Tanners Cassia Flowers for Skin Care Applications
}

\author{
Krishnaveni Vasudevan* \\ Department of Fashion Technology, Kumaraguru College of Technology, India
}

Submission: May 11, 2020; Published: August 06, 2020

*Corresponding author: Krishnaveni Vasudevan, Associate Professor, Department of Fashion Technology, Kumaraguru College of Technology, Coimbatore-641049, Tamilnadu, India

\begin{abstract}
Background: Skin care is still a challenge for the Pharmaceutical and hospital concerns, in spite of being more advanced nowadays. The purposeful necessities of skin care textiles have led to the pioneering use of diversity of natural plants with therapeutic properties for medical applications. The Tanners cassia flowers are one of the exceptionally important natural plant available in all areas with abundant germ-free properties.
\end{abstract}

Methods: In this present investigate work the Tanners cassia flowers were collected and extracted and it was coated on organic cotton fabric.

Results: The extract was tested under qualitative antimicrobial phytochemical screening and the test results revealed the presence of antimicrobial constituents. The antibacterial and antifungal activity of Tanners cassia flowers ethanolic $5 \%$ and $10 \%$ concentrated extracts were analyzed using standard AATCC 147 and AATCC 100 tests against both gram positive and gram-negative bacterial pathogens staphylococcus aureus, klebsiella pneumoniae, pseudomonas auruginosa, escherichia coli and aspergillus nigar fungi. The extract was tested under qualitative phytochemical screening, the results expressed the occurrence of major phytochemicals.

Conclusion: The activity test result also shows that the Tanners cassia treated samples has superior antibacterial and antifungal activity by zone of inhibition and it can be more apt for healthcare textiles.

Keywords: Tanners cassia, Ethanolic extract, Phytochemical Analysis, Antibacterial activity, Anti-fungal activity Micro-organisms, Skin care applications

\section{Introduction}

Skin care and tissue engineering is very important for survival mechanism to retain the function of tissues. Skin care is still a challenge for the pharmaceutical industry, despite of being more intricate at the moment. The 1-5\% of drugs only used in western pharmacopeias for curing and healing of infections in the skin. The natural plants hold massive potential to come up with extensive solution for the wound healing and various ailments $[1,2]$. The appropriate and ample nourishment is very much essence for dealing with skin and allied infections. In addition, medicinal plants are at the moment considered as prosperous source for management of skin and health care systems and an exciting number of modern drugs have been isolated from natural resources [3] Natural plants have been used for centuries as remedy for human diseases and propose a new source of biologically active chemical compounds as antimicrobial agent [4]. The wound protective materials are interrelated to the skin and are mandatory to undergo rigorous testing and germ-free criteria, which led to novel exercise of diversity of plant parts. From the plant kingdom, one of the copious sources of natural tree is Tanners cassia leaves are known to be an affluent source of constituents namely flavonol morin, and morin-3-o-lyxoside, secondary metabolites and these higher plants are widely used for medicinal practices [5]. The Tanners cassia is a phytotherapic plant which is very important in folk and traditional medicine and it is believed to have active bio components that smooth the progress to cure an assortment of skin infections [6-9].

The cassia flower extract exhibited good antimicrobial activity against nine different strains of Staphylococcus aureus [10]. The plant kingdom contains many species of plants possessing substances of medicinal value that had to be discovered Roots and flowers are useful in cures tumors, skin diseases. Decorticated seed powder and paste are treasured local applications to 
purulent opthalamia and conjunctivitis [11-13]. Despite the fact that, statistics of plants are constantly being analyzed for their antimicrobial effects still there is a search for natural antibiotic [14].

Plant-derived substances have recently become variety of phytochemicals like tannins, flavanoids and phenols of great interest owing to their versatile applications $[15,16]$. Plants containing favorable phytochemicals may supplement the requirements of the human body by acting as natural antioxidants and the solvent ethanol which may have yielded a great number of active constituents responsible for antimicrobial activity [17]. Apart from wound applications, the plant is used to develop medicated products. Hence the present research work aims at developing antimicrobial medicated fabrics for healthcare applications.

\section{Materials and Methods}

\section{Materials}

\section{Selection of Textile fabric}

Organic cotton fabric with the count of $2 \times 42$ 's and twill weave were selected for the study. The fabric was desized, scoured and bleached preceding to the application of finish [18].

\section{Sourcing of Natural plant}

The Tanners cassia flowers were selected and procured for the study based on their skin care, healing and antimicrobial properties and it was collected from Agriculture University, Coimbatore.

\section{Extraction of herbal extract}

They were Tanners cassia flowers were collected from the plant and it was shadow dried for about six days and converted into powder form by using automatic machines. 40gms of fine powder was uniformly mixed with $100 \mathrm{ml}$ of ethanol for seven hours using soxhlet apparatus by hot extraction method. After the extraction process, the solution was kept for solvent evaporation for about 9hours. Then the residue of the extract was collected and stored with tight lid in the refrigerator at $4^{\circ} \mathrm{C}$. Based on the need of requirement, the extract was diluted and utilized for further end use $[19,20]$.

\section{Application of coating on Fabric using Extract}

The organic cotton fabric samples were finished with $5 \%$ and $12 \%$ concentrated herbal extract using the material liquor ratio of $1: 10$ with optimized conditions like 30 pascal pressure at $40^{\circ} \mathrm{C}$ temperature for about $1 \mathrm{hr}$ time duration with alum mordant as cross-linking agent. The extracts were applied on to the fabric by pad dry cure method using the padding mangle and the fabric was dried and then cured at $120^{\circ} \mathrm{C}$ for 3 minutes [21].

\section{Methods}

The various methods are used for identifying the phytochemical constituents in the Tanners cassia flowers extracted solution and antimicrobial activity on treated fabric samples.

\section{Preliminary Phyto-chemical screening}

The qualitative method of phytochemical analysis is used to identify the presence of active phyto constituents in Tanners cassia extract such as alkaloids, flavanoids, phenols saponin and tannins. The preface investigation was conducted as per standard test conditions.

\section{Meyer's Test for Alkoloids}

Few drops of Meyer's reagent were mixed with $1.0 \mathrm{ml}$ of the extract, after some time the precipitate was formed in yellow creamy colour that indicates the occurrence of alkoloids.

\section{Alkaline Reagent Test for Flavanoids}

The 5 drops of sodium hydroxide solution was added to the extract solution and mixed it thoroughly. After some time, the intense yellow color was formed in the solution, then added a few drops of dilute hydrochloric acid and turned into colorless which represents the presence of flavanoids.

\section{Ferric Chloride Test for Phenols}

The $2.0 \mathrm{ml}$ of distilled water was added with $1.0 \mathrm{ml}$ of the extract followed by few drops of $10 \%$ aqueous ferric chloride solution. Blue, green, or violet color has formed indicating the presence of phenols.

\section{Ferric Chloride Test for Tannins}

Few drops of aqueous 5\% Ferric chloride were mixed with $1.0 \mathrm{ml}$ of the extract. A bluish black color was formed which then gets disappeared in addition of few drops of dilute sulphuric acid and a yellowish-brown precipitate was formed which indicates the presence of tannins [22-24].

\section{Foam Test for Saponins}

A few drops of sodium bicarbonate solution were taken with $1.0 \mathrm{ml}$ of the extract, shaken vigorously and kept for 3 minutes. A honeycomb like froth will be formed and this indicates the presence of saponins

\section{Antibacterial activity Assessment method of Tanners cassia ethanolic flowers extract (AATCC- 147 -Test Method)}

The antibacterial activity of the Tanners cassia flower extract was analyzed using AATCC standard qualitative test method of agar well diffusion method. 


\section{Preparation of bacterial cultures}

The different four bacterial cultures and two different fungal cultures were developed from Microbial Type Culture Collection (MTCC), Department of biotechnology Laboratory, Kumaraguru College of Technology, Coimbatore, India. The developed bacterial and fungal cultures for the study were namely gram-positive bacterial pathogens Staphylococcus aureus and Klebsiella pneumonia gram negative bacterial pathogens namely Pseudomonas auruginosa and Escherichia coli. The developed bacterial cultures were maintained on nutrient agar slant and were also isolated, stored separately in a refrigerator at $4^{\circ} \mathrm{C}$.

\section{Testing of Antibacterial activity by agar well diffusion method}

The antibacterial activity of Tanners cassia extract was evaluated using agar well diffusion method [25]. $20 \mathrm{ml}$ of nutrient agar was prepared and allowed for sterilization at $12^{\circ} \mathrm{C}$ for about 15 minutes. The petri plates were autoclaved in hot air oven at $121^{\circ} \mathrm{C}$ for 45 minutes. The flower ethanolic extract has been converted into $100 \mu \mathrm{g} / \mathrm{ml}$ concentration. The $20 \mathrm{ml}$ nutrient agar was poured into the petri plates and it was permitted to solidify for about 2 hours. Then the plant extract was poured in the developed well and the plates were incubated for 24 hours at $37^{\circ} \mathrm{C}$. After 24 hours, the antibacterial activity was assessed against the test organisms Staphylococcus aureus, Klebsiella pneumoniae, Pseudomonas auruginosa and Escherichia coli by measuring the zone of inhibition.

\section{Antifungal activity Assessment method of Tanners cassia ethanolic flowers extract (Broth Dilution Test)}

$300 \mathrm{ml}$ Elenmeyer conical flask containing $40 \mathrm{ml}$ of PD broth was prepared and sterilized at $121^{\circ} \mathrm{C}$ for 20 minutes. After that it was allowed to cool. Then the fabric samples were transferred aseptically into the conical flasks and were kept at room temperature for about 3 days. After the 3 days the fungi growth was observed and measured.

\section{Coating finish durability test}

The durability of the coated organic fabric was conducted for the sample of size $4 \times 4 \mathrm{~cm}$. The extract coated sample chosen for the test was washed for about 5-25 cycles in standard temperature $37^{\circ} \mathrm{C}$ and with an standard detergent.

\section{Results and Discussion}

The preliminary phytochemical screening and antimicrobial activity test results were discussed.

\section{Preliminary phytochemical screening}

The qualitative phytochemical screening of Tanners cassia extract test results is shown in the Table 1 . The results revealed the presence of phytochemical constituents in the extract such as flavanoids, phenols, tannins and alkaloids, in the Tanners cassia leaves. The precipitate color represents the presence of these components induces either individually or in combination to posses' antimicrobial activity. The active antimicrobial components such as Flavonoids are found in the extract solution and act as a barrier to control a extensive range of microorganisms due to their capacity to coalesce with additional cellular soluble proteins as well as complex with bacterial cell wall [25]. The presence of tannins in the roots Tanners cassia of implied that tannin may be the active compound which was responsible for antimicrobial activity in this study. The component tannin expresses better antibacterial activity [22-25].

Table 1: Qualitative Phytochemical Analysis of the Ethanolic Floral Extract of Tanners Cassia.

\begin{tabular}{|c|c|c|}
\hline S. No & Plant Constituents & Ethanolic Extract \\
\hline 1 & Alkaloids -Meyer's Test & + \\
\hline 2 & Flavanoids -Alkaline reagent Test & + \\
\hline 3 & Phenols- Ferric Chloride Test & + \\
\hline 4 & Tannins -Ferric Chloride Test & + \\
\hline 5 & Saponins -Foam Test & + \\
\hline
\end{tabular}

Assessment method of antibacterial activity on Tanners cassia flower ethanolic extract (AATCC- 147 -Test Method)

The antibacterial activity of the Tanners cassia flower extract has been shown in the Table 2 and Figure 1.

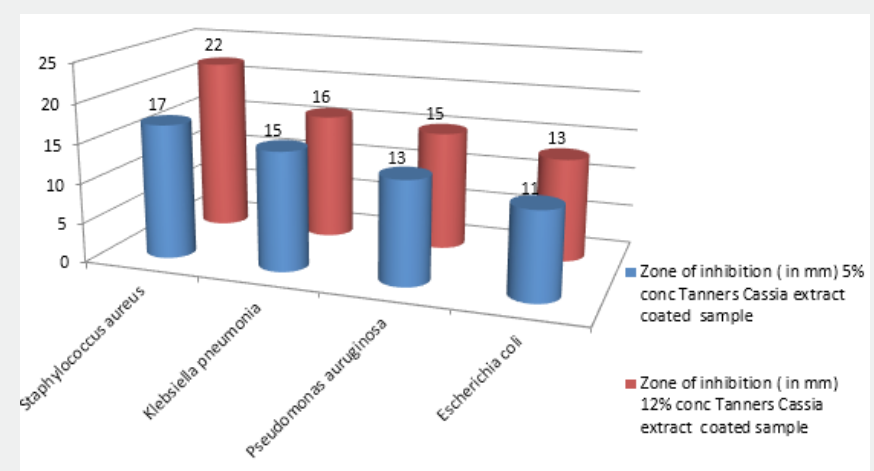

Figure 1: Antibacterial Activity of Tanners cassia Floral Extract Coated Fabric Samples. 
The zone of inhibition test results of Tanners cassia flower extract against gram positive bacterial pathogens namely Klebsiella pneumoniae, Staphylococcus aureus and gram-negative bacterial pathogens namely Pseudomonas auruginosa and Escherichia coli by agar well diffusion method were shown in (Table 2). The results of zone of inhibition showed better antibacterial activity against gram positive pathogens namely Staphylococcus aureus (22mm) and Klebsiella pneumoniae $(16 \mathrm{~mm})$ than gram negative pathogens namely Pseudomonas auruginosa $(15 \mathrm{~mm})$ and Escherichia coli $(13 \mathrm{~mm})$. in $12 \%$ conc extract coated fabric sample than $5 \%$ conc extract coated fabric sample. This plant extract showed the good results in controlling the growth of positive pathogens than compared to negative pathogens.

Table 2: Antibacterial Zone of Inhibition in ( $\mathrm{mm}$ ) Against Gram Positive and Gram-Negative Bacterial Pathogens on Ethanolic Floral Extract of Tanners Cassia.

\begin{tabular}{|c|c|c|}
\hline \multirow{2}{*}{ Test Organisms } & \multicolumn{2}{|c|}{ Zone of Inhibition (in mm) } \\
\cline { 2 - 3 } & $\begin{array}{c}\text { 5\% Conc Tanners } \\
\text { Cassia Extract Coat- } \\
\text { ed Sample }\end{array}$ & $\begin{array}{c}\text { 12\% Conc Tanners } \\
\text { Cassia Extract Coat- } \\
\text { ed Sample }\end{array}$ \\
\hline Staphylococcus Aureus & 17 & 22 \\
\hline Klebsiella Pneumonia & 15 & 16 \\
\hline $\begin{array}{c}\text { Pseudomonas Auru- } \\
\text { ginosa }\end{array}$ & 13 & 15 \\
\hline Escherichia Coli & 11 & 13 \\
\hline
\end{tabular}

\section{AATCC-30-1993: Anti-Fungal Activity- Broth Dilution} Test)

It was found that there was less growth of fungi in the conical flask containing $12 \%$ concentration sample when compared to $5 \%$ treated and untreated sample from the picture (plate -1). This indicates that the $12 \%$ treated fabric has better anti-fungal property against Aspergillus niger (Table 3 and plate 1).

Table 3: Antifungal Activity -AATCC-30 Absorbance Tests at 670Nm.

\begin{tabular}{|c|c|}
\hline \multirow{2}{*}{ Sample } & Absorbance Values (at 670nm) \\
\cline { 2 - 2 } & Aspergillus Niger \\
\hline Untreated fabric & 1.02 \\
\hline $\begin{array}{c}12 \% \text { Con Tanners Cassia } \\
\text { extract coated Sample }\end{array}$ & 0.8 \\
\hline
\end{tabular}

\section{Coating finish durability Test}

From the assorted level of wash factor results, it can be that indicated that the herbal coated organic cotton sample can withstand up to 15- 18 wash cycles is shown in (Table 4).
Table 4: Coating Durability Test.

\begin{tabular}{|c|c|c|}
\hline \multicolumn{2}{|c|}{ Wash Durability } & $\begin{array}{c}\text { Absorbance Value (at } \\
\text { 670nm) }\end{array}$ \\
\hline \multirow{2}{*}{ Uncoated Fabric } & Before wash & 1.09 \\
\hline \multirow{4}{*}{$\begin{array}{c}\text { 12\% Conc Tanners } \\
\text { Cassia Treated } \\
\text { fabric sample }\end{array}$} & After 5 wash & 0.87 \\
\cline { 2 - 3 } & After 10 wash & 0.96 \\
\cline { 2 - 3 } & After 15 wash & 0.99 \\
\cline { 2 - 3 } & After 20 wash & 1.03 \\
\cline { 2 - 3 } & After 25 wash & 1.06 \\
\hline
\end{tabular}

\section{Conclusion}

The test analysis of Tanners cassia floral extract results proved the phytochemical constituents present in the extract includes flavanoids, phenols, alkaloids, and tannins. The presence of phytocomponents such as tannins and flavanoids in the extract exhibits better antimicrobial activity. The antibacterial test results also showed superior levels of antibacterial activity in $10 \%$ conc extract treated fabric sample against gram positive bacterial pathogens namely $S$. aureus and $K$. pneumoniae than gram negative bacterial pathogens $P$. auruginosa and E. coli. The study reveals that the plant extract coated fabric is found to be very hygienic with less fungi and bacteria as well as making the cloth much softer than before. This finish is very much cost effective and eco-friendly. Based on the qualitative phytochemical screening and antibacterial activity assessments, the plant extract treated fabric samples confirmed that it will be more suitable for the skin care applications. Hence, this research work will give an idea for developing sustainable antimicrobial coated dressings for medical and protective applications in hospital field as well as raw material of organic cotton is from $100 \%$ natural resources, it is renewable and environmental benefits.

\section{Acknowledgement}

This research did not receive any specific grant from funding agencies in the public, commercial or not-for-profit sectors.

\section{Conflict of Interest}

Nil.

\section{References}

1. Csupor D, Blazo G, Balogh A, Hohmann J (2010) Traditional Hungarian Medicinal plant Centaurea sadleriana Janka accelerates wound healing in rats. J Ethano 127(1): 193-195.

2. Mensah JK, Okoli RI, Turay AA, Ogie-Odia EA (2009) Phytochemical analysis of medicinal plants used for the management of hypertension by Esan people of Edo state, Nigeria. Ethnobot leaflets 13(10): 12731287.

3. Devprakash, Srinivasan KK, Subburaju T, Sachin kumar singh (2011) Antimicrobial activity of alcoholic and aqueous extracts of Vetiveria zizanioides. J Phar Res 4(5): 1343-1344.

4. Tanaka J, Da Silva C, De Oliveira A, Nakamura C, Dias Filho B (2006) Antibacterial activity of indole alkaloids from Aspidosperma ramiflorum. Brazilian journal of medical and biological research 39(3): 387-391. 
5. Ajiboye Adeyinka Elizabeth, Ameen Muhammad Tukur, Adedayo Majekodunmi (2015) Antimicrobial activity and phytochemical screening of the fruit pulp of Dialium guineense (Velvet Tamarind) on some microbial isolates. J Micr ant 7(4): 33-41.

6. Abdelrahim, Almagboul Omer, Elegami (2002) Antimicrobial activity of Tanners cassia L Fitoterapia 73(7-8): 713-715.

7. Jaiarj, Khoohaswan, Wongkrajanga Peungvicha, Suriyawong, Saraya (1999) Anticough and antimicrobial activities of Tanners cassia Linn flower extract. J Ethnopharm 67(2): 203-212.

8. Lutterodt (1992) Inhibition of Microlax-induced experimental diarrhoea with narcotic-like extracts of Tanners cassia flower in rats. J Ethnopharm 37(2): 151-157.

9. Bipul Biswas, Kimberly Rogers, Fredrick McLaughlin, Dwayne Daniels, Anand Yadav (2013) Antimicrobial Activities of Flower Extracts of Guava (Tanners cassia L) on Two Gram-Negative and Gram-Positive Bacteria. Inter J Micro 10: 1-7.

10. Krishnaveni Vasudevan (2017) Effect of Imparting Antimicrobial Coating on Organic cotton Fabric Using Yashtimadhu for Medical Application. J Textile Eng Fashion Technol 3(3): 1-4.

11. Ravikumar V, Shivashangari KS, Devaki T (2005) Effect of Tridax procumbens on liver antioxidant defense system during lipopolsaccharidinduced in Dgalactosomine sensitized rats. Mol Cell Biochem 269(1-2): 131-136.

12. Vyas P Suresh, Tiwari Umesh, Rastogi Bhawna, Dinesh K Saraf, Suresh P Vyas (2004) Immunomodulatory effects of aqueous extract of Tridax procumbens in experimental animals. Journal of Ethnopharmacologoly 92(1): 113-119.

13. Devados K, Raja SJ Nattanmai, Rajappan M (2013) In vitro antimicrobial activity and phytochemical analysis of Cassia auriculata Linn. Int Cur Phar J 2(6): 105-108.

14. Shelar PS, Reddy G, Shelar, Reddy V (2012) Medicinal value of mangroves and its antimicrobial properties - A review Continental. J Fish Aqua Sci 6: 26-37.

15. Gislene G, Nascimenta F, Locatelli J, Freitas PC, Silva GL (2000) Antibacterial activity of plant extract and phytochemicals on antibiotic resistant bacteria. Brazilian J Microbiol 31: 247-246.
16. Solomon Charles Ugochukwu, Arukwe Uche I, Onuoha Ifeanyi (2013) Preliminary phytochemical screening of different solvent extracts of stem bark and roots of Dennetia tripetala. Asian J Plant Sci and Res $3(3): 10-13$

17. Boots AW, Haenen GR, Bast A (2008) Health effects of quercetin: From antioxidant to nutraceutical. Eur J Pharmacol 585(2-3): 325-337.

18. Krishnaveni V, Srinivasan J (2017) Investigation of Phytochemical and Anti-Bacterial Activity on Rhizophora Apiculata Ethanolic Extract for Medical Textile Applications. AJ Micr Bio Env Sci 19(11): 8-11.

19. Krishnaveni V, Aparna B (2014) Micro Encapsulation of Copper Enriched Aloe Gel Curative Garment for Atopic Dermatitis. Ind J Trad Kno 13(4): 795-803.

20. Krishnaveni V, Ampritha S (2016) Analysis of Phytochemical and Anti-Microbial Activity on Vetiveriazizanioides Ethanolic Extract for Healthcare Applications. I J Phar Bio Sci 7(2):758-765.

21. Krishnaveni V (2017) Investigation of Phytochemical and Anti-Bacterial Activity on Agave Americana Methanolic Extract for Medical Applications. Int J Phar Bio Sci 8(3): 500-505

22. Krishnaveni V, Ampritha S (2018) Application of Vetiver Extract on Organic cotton Fabric for Developing Healthcare Products. In: Parthiban M, Srikrishnan MR, Kandhavadivuin P $1^{\text {st }}$ (edn.), Chapter 3 in the book on Sustainability in Fashion and Apparels: Challenges. WPI Publishing, USA, pp. 21-27.

23. Patil US, Deshmukh OS (2016) Preliminary phytochemical screening of six medicinal plants used as traditional medicine. Int J Pharm Bio Sci 7(1): 77-81.

24. Mahesha MP, Kanivebagilu AV, Airody VA (2015) Extraction, characterization and biological studies of phytochemicals from Mammea suriga. J Pharm Ana 5(3):182-189.

25. Basari DF, Fan SH (2005) The potential of aqueous and acetone extracts of galls of Quercus infectoria as bacterial agents. Indian J Pharmacol 37(1): 26-29.

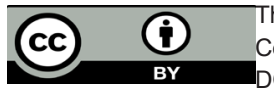

This work is licensed under Creative Commons Attribution 4.0 Licens

DOI: 10.19080/CTFTTE.2020.07.555701
Your next submission with Juniper Publishers will reach you the below assets

- Quality Editorial service

- Swift Peer Review

- Reprints availability

- E-prints Service

- Manuscript Podcast for convenient understanding

- Global attainment for your research

- Manuscript accessibility in different formats

( Pdf, E-pub, Full Text, Audio)

- Unceasing customer service

Track the below URL for one-step submission https://juniperpublishers.com/online-submission.php 